\title{
Correlation of the iron level in the bristles of Kemerovo pigs with macro- and essential microelements
}

\author{
Andrey Nazarenko ${ }^{1,{ }^{*}}$, Olga Zaiko ${ }^{2}$, Olga Korotkevich $^{1}$, Tatyana Konovalova ${ }^{1}$, and Lyibov \\ Osintseva $^{1}$ \\ ${ }^{1}$ Novosibirsk State Agrarian University, Biology and Technology Faculty, 630039 Dobrolyubova St \\ 160 , Novosibirsk, Russia \\ ${ }^{2}$ Novosibirsk State Agrarian University, Faculty of Veterinary Medicine, 630039 Dobrolyubova St \\ 160, Novosibirsk, Russia
}

\begin{abstract}
Correlation data analysis of the iron content with macro- and essential microelements, as well as on the group of chemical elements interrelated with the Fe level in pig bristles are presented. The studies were carried out of the Kemerovo region on six-month-old pigs of the Kemerovo breed. Chemical analysis of swine bristle samples was carried out using atomic absorption spectrometry. The data were processed using of the program R. Only positive relationships were established between the iron content and the chemical elements of the bristle, as well as the group of chemical elements associated with the Fe level in the bristle. Most of the connections are explained by comparing the data obtained with the research of other scientists on the topic.
\end{abstract}

\section{Introduction}

From time immemorial it has been known that a lack or excess of any substance, no matter of natural or artificial origin, has a noticeable effect on the body of any living creature. The effect of a chemical element on the body is determined by a number of characteristics, which include absorption, metabolism and synergism. Iron is the most important element if we consider it from the point of view of physiological systems, since it is this chemical element that is involved in a wide range of metabolic processes, taking part in the transport of oxygen, the synthesis of deoxyribonucleic acid (DNA) and the transport of electrons at the cellular level. But, since this microelement is prone to the formation of free radicals, due to which oxidative processes are observed in the body, leading to tissue damage, then its content in organs and tissues should be regulated in the strictest manner. Disorders associated with iron metabolism affect a variety of aspects of the physiology of the body and have non-standard pictures of clinical manifestations, from simple anemia to complex neurodegenerative and other diseases of complex etiology [1-6].

Unlike many other trace minerals, iron is the most abundant in the environment. However, despite its geological abundance, it is also a stumbling block between the environment and

\footnotetext{
* Corresponding author: andrey2221100@mail.ru
} 
mineral deposits, since in its usual form, this trace element is subject to oxidative processes in air, while a large number of oxides insoluble in water are formed, and accordingly there is no question on the absorption of these substances by neither plants nor animals. The paradox is obvious, as they say. But do not exaggerate, because in response to this state of affairs, various mechanisms of cellular catabolism have evolved over time to such an extent that they are able to capture iron from the environment in biological forms available to the body. Like examples of such mechanisms are siderophores, these are low molecular weight substances of different chemical structures that are secreted by microbes to capture iron in a highly specific complex, while insoluble ferric iron entering the body is oxidized to a more accessible bivalent. In the human body and many other mammals, iron mainly exists in complex complexes, where it is associated with the hemoprotein protein, in the form of heme compounds, representing hemoglobin or myoglobin, as well as heme enzymes and other compounds. Almost two-thirds of the iron in the body is contained in circulating red blood cells in the form of hemoglobin, a quarter is contained in an easily mobilized reserve, and the remaining one-sixth is associated with myoglobin in muscle tissue and various enzymes [7$10]$.

Thus, this microelement is processed in the body and stored for subsequent biochemical processes aimed at maintaining the homeostasis of living systems. The only physiological way of removing iron from the body is by replacing the epithelium, in other cases, an excess concentration of this metal is removed only under the condition of trauma associated with blood loss. It should be noted that the proportion of absorbed iron from the total amount supplied is quite small and varies widely from $4-40 \%$, depending on a number of factors. The absorption of this element occurs at the expense of intestinal enterocytes by means of a special carrier from the group of membrane transport proteins. Absorption occurs mainly in the duodenum and upper jejunum. Then adhesion occurs through the mucous membrane of the duodenum into the blood, where, with the help of transferrin, ferrous iron is transferred to the cells or bone marrow for further erythropoiesis. The main factor determining the absorption of iron in the duodenum is its physiological state, since, as mentioned above, $\mathrm{Fe}^{2+}$ is rapidly oxidized to the insoluble form of $\mathrm{Fe}^{3+}$. At the same time, the $\mathrm{pH}$ of the proximal duodenum decreases under the action of gastric acid, as a result of which the solubility and absorption of $\mathrm{Fe}^{3+}$ increases due to the oxidation of iron reductase to $\mathrm{Fe}^{2+}$, thereby providing transport across the cell membrane of intestinal cells. If the secretion of gastric juice is disturbed, then the absorption of iron decreases many times [11-14].

Dietary heme is also transported across the apical membrane of enterocytes and subsequently catabolized by heme oxygenase to ferrous iron. This process does not depend on the $\mathrm{pH}$ of the duodenum and is most effective. Thus, it is not affected by inhibitors such as phytate and polyphenols. As for transferrin, its $\mathrm{Fe}^{2+}$ pool is replenished mainly due to iron obtained during recirculation from dead erythrocytes and already absorbed food heme. As for iron stores in the body, two protein complexes are responsible for their pool - ferritin and hemosiderin. They are localized mainly in the liver, spleen and bone marrow [15-18].

There are two forms of dietary iron - heme and non-heme. Hemoglobin and myoglobin are heme forms, while non-heme iron is found mainly in plant foods such as legumes, cereals, fruits and vegetables. With regard to the bioavailability of these forms, it is obvious that heme iron is absorbed better than non-heme and, as mentioned earlier, the absorption of the heme form is not influenced by a number of factors, while the absorption of non-heme iron depends on many factors. These factors include polyphenols, phytic acid, calcium and some peptides that inhibit the absorption of this chemical element. Activators include vitamin C $[19,20]$.

The body always needs a constant balance between absorption, transport, storage and utilization of externally supplied iron. As mentioned above, there are no active ways to remove this trace element from the body. That is why the balance is regulated at the point of absorption by the peptide hormone hepcidin, which is secreted by the liver. It is the main 
regulator of iron homeostasis in the body. Its principle of action is based on binding to ferroportin, which further leads to the degradation of the latter. Thus, iron is prevented from entering the plasma, which leads to a balance in the absorption of this chemical element by erythroblasts $[21,22]$.

Other heavy metals such as $\mathrm{Pb}, \mathrm{Mn}, \mathrm{Co}$ and $\mathrm{Zn}$ act as competitors for the absorption of iron in the body. Of the microelements presented, only lead has the greatest negative effect on iron metabolism due to competitive inhibition and general intoxication of the body [23, 24].

The aim of the study is to establish correlations between the accumulation of iron in the bristles of pigs of the native Kemerovo breed with macro- and essential microelements.

\section{Materials and methods}

The studies were carried out on pigs of the Kemerovo breed in Western Siberia [25]. In the breeding region, the enterprise used a single diet, balanced in macro- and microelement, as well as vitamin and amino acid composition [26]. Bristle samples were taken from 26 pigs 6-7 months of age, taking into assesment GOST 7269-2015 «Methods of sampling and organoleptic methods for determining freshness» [27], GOST 22384-77 «Combined bristles. Raw materials. Technical conditions» [28].

In the breeding zone of this pig breed, the soil, water, feed, organs and tissues of various animal species were examined for the content of iron and other heavy metals, the level of which did not exceed the MPC [29].

The research was carried out on laboratory of elementology of agricultural animals of the Federal State Budgetary Educational Institution of Higher Education «Novosibirsk State Agrarian University» with the use of an atomic absorption spectrometer MGA-1000 (LLC «Lumex», Russia).

All parameters were tested for normal distribution using the Shapiro-Wilk test (W). The correlation between normally distributed traits was assessed using the Pearson's correlation coefficient. Statistical data processing was carried out using standard software from the Microsoft office package and the R program.

The reported study was funded by RFBR according to the research project № 20-316-90029.

\section{Results and discussion}

Table 1 presents data on the correlation of the level of iron in the bristles of pigs with macroand essential microelements.

Table 1. Correlation of the level of iron in the bristles of pigs of the Kemerovo breed with macro- and essential microelements.

\begin{tabular}{|c|c|c|}
\hline Correlated parameters & $\mathrm{r} \pm \mathrm{S}_{\mathrm{r}}$ & $\mathrm{P}$ \\
\hline $\mathrm{Fe}-\mathrm{P}$ & $0,678 \pm 0,15$ & $<0,001$ \\
\hline $\mathrm{Fe}-\mathrm{Ca}$ & $0,693 \pm 0,147$ & $<0,001$ \\
\hline $\mathrm{Fe}-\mathrm{Mg}$ & $0,602 \pm 0,163$ & $<0,01$ \\
\hline $\mathrm{Fe}-\mathrm{Mn}$ & $0,78 \pm 0,128$ & $<0,001$ \\
\hline $\mathrm{Fe}-\mathrm{Cu}$ & $0,541 \pm 0,172$ & $<0,01$ \\
\hline $\mathrm{Fe}-\mathrm{Cd}$ & $0,593 \pm 0,164$ & $<0,01$ \\
\hline
\end{tabular}

The ferritin nucleus contains not only iron, but also phosphorus. Moreover, there is a direct relationship between the content of these elements in this protein complex [30]. A study by Bo Lönnerdal in humans showed that there is a close relationship between iron and calcium, since $\mathrm{Ca}$ inhibits the absorption of $\mathrm{Fe}$ in the body through transporters such as 
DMT1, FPN1, and hefestin [31]. There is evidence of a protective effect of magnesium against oxidative damage in rats caused by free iron. When the level of magnesium in red blood cells is low, the concentration of iron increases, but the number of red blood cells decreases. In this case, erythrocytes have a disrupted structure and functional activity, which leads to a decrease in the level of hemoglobin and, anemia, respectively [32]. Overloading with manganese as well as with iron induces oxidative activity. But, on the other hand, if these two processes occur simultaneously, then they neutralize the action of each other. Manganese is a cofactor for the antioxidant MnSOD, which is exclusively expressed in mitochondria. Its protective effect against iron overload is associated with a reduction in oxidative stress by increasing antioxidant activity and restoring the function of a number of monoaminergic proteins [33]. Copper is closely related to iron, as both are essential for proper erythropoiesis. Moreover, the balance of copper in the body is closely related to the absorption of iron, since $\mathrm{Fe}$ and $\mathrm{Cu}$ have similar physicochemical and toxicological properties [34]. The absorption of cadmium in the body increases in direct proportion to iron deficiency, since $\mathrm{Cd}$ and $\mathrm{Fe}$ are antagonists and have common contact pathways. Experiments on rats have shown that cadmium inhibits the activity of DMT1 and FPN1 in the duodenum, thereby releasing ferric iron, which leads to abnormal absorption of this trace element [35]. Therefore, the obtained high positive relationship with a $99 \%$ significance level between the level of iron and cadmium in the bristles defies logical explanation, since the hair is very well supplied with blood, in which there is a high concentration of ferritin and other metal transporters, which was mentioned earlier and more than once, but at the same time there is a close relationship between the deposited $\mathrm{Cd}$ and Fe. Paradox.

To exclude the factor of mediation of correlations between iron and the presented macroand microelements, connections were additionally established for the main correlating signs.

Table 2. Correlations of macro- and essential microelements associated with the level of iron in the bristles of pigs.

\begin{tabular}{|c|c|c|}
\hline Correlated parameters & $\mathrm{r} \pm \mathrm{S}_{\mathrm{r}}$ & $\mathrm{p}$ \\
\hline $\mathrm{P}-\mathrm{Ca}$ & $0,694 \pm 0,147$ & $<0,001$ \\
\hline $\mathrm{P}-\mathrm{Mg}$ & $0,814 \pm 0,119$ & $<0,001$ \\
\hline $\mathrm{P}-\mathrm{Cu}$ & $0,706 \pm 0,145$ & $<0,001$ \\
\hline $\mathrm{P}-\mathrm{Cd}$ & $0,695 \pm 0,147$ & $<0,001$ \\
\hline $\mathrm{P}-\mathrm{Mn}$ & $0,907 \pm 0,086$ & $<0,001$ \\
\hline $\mathrm{Ca}-\mathrm{Mg}$ & $0,818 \pm 0,117$ & $<0,001$ \\
\hline $\mathrm{Ca}-\mathrm{Mn}$ & $0,907 \pm 0,086$ & $<0,01$ \\
\hline $\mathrm{Ca}-\mathrm{Cu}$ & $0,565 \pm 0,168$ & $<0,001$ \\
\hline $\mathrm{Mn}-\mathrm{Mg}$ & $0,811 \pm 0,119$ & $<0,001$ \\
\hline $\mathrm{Mn}-\mathrm{Cu}$ & $0,741 \pm 0,137$ & $<0,001$ \\
\hline
\end{tabular}

Phosphorus and calcium are related to each other, since both are part of the parathyroid hormone. There is a positive association between serum phosphorus and calcium hormones with parathyroid monomer, especially in patients with chronic kidney disease [36]. Magnesium, calcium and phosphorus are closely related to each other. There is evidence that with an increase in the concentration of magnesium in the blood serum, the content of parathyroid hormone also increases, which, in turn, regulates the synthesis of calcium and phosphorus in the blood, their metabolism in the body. It should be noted that with a deficiency of phosphorus, the concentration of $\mathrm{Mg}$ and $\mathrm{Ca}$ in the urine increases. This effect is observed in premature babies [37]. Phosphorus and magnesium are deposited in addition to the bristle and in the bone tissue, where they participate in the synthesis of ATP, mainly for the bone marrow [38]. The high positive relationship between phosphorus and cadmium levels defies description from the literature. Since $\mathrm{Mn}$ is a cofactor of manganese-dependent superoxide dismutase, which has an antioxidant effect on the processes of overloading the 
body with various microelements, it is able to restore the functions of monoaminergic proteins, some of which are involved in various metabolic processes. The positive correlation between calcium and copper levels is due to the fact that an increase in serum calcium concentration leads to retention of copper in the body. This effect is due to the fact that $\mathrm{Ca}$ neutralizes the action of ascorbic acid, which, in turn, prevents the absorption of copper [39]. The relationship between the concentration of manganese and magnesium is due to the fact that both elements compete with each other and with other divalent cations for a common transport «network» [40]. But, in this case, with a deficit of one of them, the level of the other should increase, which does not happen upon closer examination of the data we obtained. It is obvious that manganese is involved in decarboxylation processes and also serves as an activator of a number of enzymes in the Krebs cycle. Copper also affects the activity of several enzymes involved in the same cycle [41, 42].

\section{Conclusions}

In the bristles of the Kemerovo breed pigs, positive correlations were established between the level of iron and macro- and essential microelements. Many connections have been revealed between macro- and microelements associated with the concentration of iron in the bristles. When comparing the obtained data with the literature data, all relationships were described, except for the content of iron and cadmium in the bristles of pigs $(r=0.59)$.

The obtained correlations, as well as a change in their strength, may indicate a genotypic component.

\section{References}

1. N. Abbaspour, R. Hurrell, R. Kelishadi, J. Res. Med. Sci. 19(2), 164-174 (2014)

2. Y. Li, W. Yang, D. Dong, S. Jiang, Z. Yang, Y. Wang, Anim Nutr. 4(2), 197-202 (2018)

3. J. Kals, R.J.W. Blonk, H.W. van der Mheen, J.W. Schrama, J.A.J. Verreth, Aquaculture 451, 266-270 (2016)

4. Y.M. Zhang, D. Wan, X.H. Zhou, C.M. Long, X. Wu, L. Li., Biochem Biophys Res Commun 490, 1210-1214 (2017)

5. E.C. Theil, H. Chen, C. Miranda, H. Janser, B. Elsenhans, M.T. Núñez, F. Pizarro, K. Schümann. J. Nutr. 142, 478-483 (2012)

6. T.D. Johnson-Wimbley, D.Y. Graham, Ther. Adv. Gastroenterol 4, 177-184 (2011)

7. O.S. Korotkevich, O.A. Zheltikova, V.L. Petukhov, Reports of the Russian Academy of Agricultural Sciences 4, 41-43 (2009)

8. O.A. Zaiko Variability and correlation of chemical elements in organs and tissues of pigs of early maturing meat breed SM-1. 183 (Novosibirsk, 2014)

9. M.V. Strizhkova Content, variability and correlation of macroelements in organs and tissues of black-and-white cattle, 126 (Novosibirsk, 2018)

10. S.E. Cox, V. L'Esperance, J. Makani, D. Soka, A.M. Prentice, C.M. Hill, F.J. Kirkham. J. Clin. Sleep. Med. 8, 541-545 (2012)

11. P. Scheinberg, J. Chen. Semin Hematol 50, 156-64 (2013)

12. T.V. Konovalova, Novosibirsk State Technical University 111 (2014)

13. O.A. Zaiko, A.V. Nazarenko, I.A. Koroleva, M.A. Romanenko, S.N. Mager. Syberian Herald of Agricultural Science 1(51), 90-98 (2021) 
14. K.N. Narozhnykh, T.V. Konovalova, Y.I. Fedyaev, N.I. Shishin, A.I. Syso, O.I. Sebezhko, V.L. Petukhov, O.I. Korotkevich, E.V. Kamaldinov, L.V. Osadchuk. Indian Journal of Ecology. 44(2), 217-220 (2017)

15. A.V. Nazarenko, O. I. Sebezhko, Yu.V. Volkov, O.S. Korotkevich, E.V. Fikhman, E.P. Mazurina, 1, 419-422 (2017)

16. A.V. Nazarenko, O. I. Sebezhko, E.V. Fikhman, E.P. Mazurina, 124-127 (2018)

17. A. V. Nazarenko, O.A. Zaiko, T.V. Konovalova, O.I. Sebezhko, M.V. Strizhkova, O.S. Korotkevich, K.N. Narozhnykh, V.L. Petukhov, V.A. Andreeva, Trace Elements and Electrolytes, 38(3), 150 (2021)

18. J. Liang, B.Z. Han, M.J.R. Nout, RJ. Hamer. Food Chem. 110, 821-828 (2008)

19. A.V. Nazarenko, 386-391 (2019)

20. N. Roohani, R. Hurrell, R. Kelishadi, R. Schulin. J. Res. Med. Sci. 18, 144-157 (2013)

21. J. Wang, K. Pantopoulos. Biochem. J. 434, 365-381 (2011)

22. V.L. Petukhov, I.A. Afonina, M.A. Kleschev, O.I. Sebezhko O.S. Korotkevich, N.M. Kostamakhin, T.V. Konovalova, K.N. Narozhnykh, D.S. Adushinov, G.M. Goncharenko, A.G. Nezavitin, I.I. Klimenok, A.V. Nazarenko, E.A. Klimanova, L.V. Osadchuk. Indian Journal of Ecology. 46(4), 901-906 (2019)

23. B.L. Panov, V.L. Petukhov, L.K. Ernst, I.I. Gudilin, S.G. Kulikova, O.S. Korotkevich, V.N. Dementyev, N.N. Kochnev, V.G. Marenkov, M.L. Kochneva. Problems of Farm Animal Breeding, 283 (1997)

24. O.A. Zaiko, O.S. Korotkevich, V.L. Petukhov, 6, 35-40 (2013)

25. J. Chen, P. Ni, T.N. Thi Tran, E.V. Kamaldinov, V.L. Petukhov, J. Han, X. Liu, N. Šprem, S. Zhao. Ecology and Evolution 8(16), 8102-8114 (2018)

26. A.I. Syso, V.A. Sokolov, V.L. Petukhov, M.A. Lebedeva, A.S. Cherevko, O.I. Sebezhko, T.V. Konovalova, O.S. Korotkevich, K.N. Narozhnykh, E.V. Kamaldinov. Journal of Pharmaceutical Sciences and Research 9(4), 368-374 (2017)

27. GOST 7269-2015. Sampling methods and organoleptic methods for determining freshness. - Introduced for the first time; entered 2017-01-01, 13 (M.: IPK Publishing house of standards, 2016)

28. GOST 22384-77. Combined bristles. Raw materials. Technical conditions. - Introduced for the first time; entered 1978-01-01, 7 (M.: State Committee of Standards of the Council of Ministers of the USSR, 1977)

29. K.N. Naroznykh, Variability, correlations and the level of heavy metals in organs and tissues of Hereford cattle in the conditions of Western Siberia, 163 (Novosibirsk, 2019)

30. D. de Silva, J.H. Guo, S.D. Aust Arch. Biochem Biophys. 303(2), 451-455 (1993)

31. Lönnerdal B. Int J Vitam. Nutr. Res. 80(4-5), 293-299 (2010)

32. A.S. Fabiane, M.F. Mayara, H.S. Cristiane, M.C. e S. Danilla, J.C.C. Kyria, E.O. Francisco, C. Celia, do N.M. Dilina. Nutr. Hosp. 30(3), 570-576 (2014)

33. Q. Ye, J.E. Park, K. Gugnani, S. Betharia, A. Pino-Figueroa, J. Kim. Metallomics 9(8), 1028-1046 (2017)

34. J-H. Ha, C. Doguer, X. Wang, S.R. Flores, J.F. Collins. PLoS ONE 11(8), (2016)

35. Y. Fujiwara, J.Y. Lee, H. Banno, S. Imai, M. Tokumoto, T. Hasegawa, Y. Seko, H. Nagase, M. Satoh. Toxicol Lett. 332, 130-139 (2020) 
36. L.P. Adhikary, S.K. Yadava, A. Pokharel, D. Khadka, R.J. Thakur. Nepal Health. Res. Counc. 13(29), 50-53 (2015)

37. L. Paunier, Monatsschr. Kinderheilkd 140(9 Suppl 1), 17-20 (1992)

38. I.V. Tereshchenko, Clinical Medicine, 86(7), 47-51 (2008)

39. C. Kies, J.M. Harms. 45-58 (1989)

40. S-M. Nuria, M.P. Elena, A. Pilar, L. Juan. Journal of the American College of Nutrition 18(5), 475-80 (1999)

41. M.M. Lauer, C.B. de Oliveira, N.L. Yano, A. Bianchini, Comp. Biochem. Physiol. C. Toxicol. Pharmacol 156(3-4), 140-147 (2012)

42. A. Agarwal, S. Avarebeel, N.S. Choudhary, M. Goudar, C. Tejaswini. Journal of Clinical and Diagnostic Rsearch, 11(9), 25-28 (2017) 